\title{
Commerce Clause Restraints on State Taxation: Purposeful Economic Protectionism and Beyond
}

Walter Hellerstein

University of Georgia School of Law, wallyh@uga.edu

p bepress SSRN

\section{Repository Citation}

Walter Hellerstein, Commerce Clause Restraints on State Taxation: Purposeful Economic Protectionism and Beyond (1987),

Available at: https://digitalcommons.law.uga.edu/fac_artchop/312

This Article is brought to you for free and open access by the Faculty Scholarship at Digital Commons @ University of Georgia School of Law. It has been accepted for inclusion in Scholarly Works by an authorized administrator of Digital Commons @ University of Georgia School of Law. Please share how you have benefited from this access For more information, please contact tstriepe@uga.edu. 


\title{
CORRESPONDENCE
}

\section{Commerce Clause Restraints on State Taxation: Purposeful Economic Protectionism and Beyond}

\author{
Walter Hellerstein*
}

Few questions in recent years have spawned as much controversy and as little academic interest as the scope of commerce clause restraints on state tax power. The Supreme Court has handed down an extraordinary number of significant decisions addressed to the limitations the commerce clause imposes on state taxation. ${ }^{1}$ Yet these decisions have barely caught the eye of the nation's leading law reviews ${ }^{2}$ or constitutional scholars. ${ }^{3}$ Even those observers who have recognized the Court's renaissance of interest in the dormant commerce clause have largely confined their attention to state regulation, as distinguished from state taxation, of interstate commerce. ${ }^{4}$ If there is an

* Professor of Law, University of Georgia. A.B. 1967, Harvard University; J.D. 1970, University of Chicago. - Ed.

1. Over the past decade, the Court has averaged better than a decision a year addressed in whole or in part to commerce clause restraints on state taxation. See Wardair Canada, Inc. v. Florida Dept. of Revenue, 106 S. Ct. 2369 (1986); Bacchus Imports, Ltd. v. Dias, 468 U.S. 263 (1984); Armco, Inc. v. Hardesty, 467 U.S. 638 (1984); Westinghouse Elec. Corp. v. Tully, 466 U.S. 388 (1984); Container Corp. of America v. Franchise Tax Bd., 463 U.S. 159 (1983); Commonwealth Edison Co. v. Montana, 453 U.S. 609 (1981); Maryland v. Louisiana, 451 U.S. 725 (1981); Exxon Corp. v. Wisconsin Dept. of Revenue, 447 U.S. 207 (1980); Mobil Oil Corp. v. Commissioner of Taxes, 445 U.S. 425 (1980); Japan Line, Ltd. v. County of Los Angeles, 441 U.S. 434 (1979); Moorman Mfg. Co. v. Bair, 437 U.S. 267 (1978); Department of Revenue v. Association of Wash. Stevedoring Cos., 435 U.S. 734 (1978); United States Steel Corp. v. Multistate Tax Commn., 434 U.S. 452 (1978); Complete Auto Transit, Inc. v. Brady, 430 U.S. 274 (1977); National Geographic Socy. v. California Bd. of Equalization, 430 U.S. 551 (1977); Boston Stock Exch. v. State Tax Commn., 429 U.S. 318 (1977). The Court will have rendered two more such decisions by the time these comments see the light of day. Tyler Pipe Indus. v. Washington Dept. of Revenue, 107 S. Ct. 2810 (1987); American Trucking Assns. v. Scheiner, 107 S. Ct. 2829 (1987).

2. Other than a few case notes in the Harvard Law Review's annual survey of Supreme Court opinions, and my own efforts to explicate the Court's commerce clause decisions, see, e.g., Hellerstein, State Income Taxation of Multijurisdictional Corporations: Reflections on Mobil, Exxon, and H.R. 5076, 79 MiCH. L. Rev. 113, 130-39, 151-53 (1980); Hellerstein, State Taxation and the Supreme Court: Toward a More Unified Approach to Constitutional Adjudication?, 75 Mich. L. REV. 1426, 1441-46 (1977), one will search in vain in the leading law reviews for sustained discussions of the Court's dormant commerce clause opinions addressed to state taxation.

3. One happy exception is Lockhart, A Revolution in State Taxation of Commerce?, 65 MINN. L. REV. 1025 (1981).

4. See Eule, Laying the Dormant Commerce Clause to Rest, 91 YALE L.J. 425, 426 n.2 (1982); Maltz, How Much Regulation is Too Much - An Examination of Commerce Clause Jurisprudence, 50 GEO. WASH. L. REV. 47, 49 n.8 (1981); Smith, State Discriminations Against Interstate Commerce, 74 CALIF. L. REv. 1203 (1986); Tushnet, Rethinking the Dormant Com- 
explanation for this puzzling neglect of state taxation, it may lie in the remark of Gerald Gunther - who unceremoniously dropped the subject from his casebook - that "pursuit of the intricacies of state taxation ... would require more time and space than the undertaking warrants."5

Given the current turn in academic fashion, Donald Regan's characteristically thoughtful examination of the Court's commerce clause jurisprudence in The Supreme Court and State Protectionism: Making Sense of the Dormant Commerce Clause ${ }^{6}$ assumes an added dimension because it discusses matters involving state taxation of interstate commerce. Although state taxation is not the principal focus of Regan's analysis, his thoughts concerning the Court's state tax decisions raise questions that merit further comment for two reasons: first, they shed additional light on Regan's central thesis; second, they are worthy of consideration in their own right.

\section{I}

Donald Regan's central thesis is that the Supreme Court should be and has been exclusively concerned with purposeful economic protectionism in adjudicating commerce clause challenges to state regulation of interstate commerce involving movement of goods. In nearly two hundred pages of elaborately reasoned (if somewhat breezily articulated) argument, Regan seeks to demonstrate that judicial invalidation of state legislation in these cases is theoretically justified only when the legislation was adopted for the purpose of improving the competitive position of in-state economic actors over their out-of-state competitors; that the Court's decisions are consistent with this theory; and that talk of "balancing" in the Court's opinions, which conventional wisdom takes seriously, amounts to little more than rhetorical window dressing.

Regan acknowledges that some of the Court's commerce clause decisions do not fit into this mold. In particular, he points to state regulation of interstate transportation and state taxation of interstate commerce as "areas in which the Court appears to do more under the dormant commerce clause than merely suppress state protectionism."7 With regard to state taxation, Regan observes that neither the Court's

merce Clause, 1979 WIS. L. REv. 125. But see Sedler, The Negative Commerce Clause as a Restriction on State Regulation and Taxation: An Analysis in Terms of Constitutional Structure, 31 WAYNE L. REV. 885 (1985).

5. G. GUNTHER, Constitutional LaW 332-33 (11th ed. 1985).

6. 84 MiCH. L. REV. 1091 (1986).

7. Id. at 1182 . 
insistence under the commerce clause that taxes be fairly apportioned ${ }^{8}$ nor its disapproval of flat-rate taxes ${ }^{9}$ can be explained on the basis of the anti-protectionism principle. These cases reflect an additional principle that businesses operating in more than one state should not be subjected to heavier tax burdens than businesses operating in a single state "just because they operate in more than one state."10

The Court's decisions in the state tax field, no less than its decisions in other areas of commerce clause adjudication, reveal a vigilant concern with purposeful economic protectionism. ${ }^{11}$ But these decisions, as Regan recognizes, have plainly gone further:

The vice characteristic of those [taxes] which have been held invalid is that they have placed on the commerce burdens of such a nature as to be capable, in point of substance, of being imposed or added to with equal right by every state which the commerce touches, merely because interstate commerce is being done, so that without the protection of the commerce clause it would bear cumulative burdens not imposed on local commerce. ${ }^{12}$

More recently, the Court has framed this requirement as one of " internal consistency - that is the [tax] must be such that, if applied by every jurisdiction,' there would be no impermissible interference with free trade." 13

Although Regan makes no pretense of comprehensively analyzing the Court's state tax decisions, his treatment of them raises the question whether the two concerns he has identified - purposeful economic protectionism and cumulative tax burdens - can explain their results. The Court's decisions over the past decade invalidating state taxes on commerce clause grounds ${ }^{14}$ suggest an affirmative answer. In Bacchus Imports, Ltd. v. Dias, ${ }^{15}$ the Court struck down a tax exemption for locally produced alcoholic beverages where the legislature's avowed purpose was to favor local over out-of-state goods. ${ }^{16}$ In West-

8. See, e.g., Norfolk \& W. Ry. v. Missouri State Tax Commn., 390 U.S. 317 (1968).

9. See, e.g., Nippert v. City of Richmond, 327 U.S. 416 (1946).

10. Regan, supra note 6, at 1186.

11. See, eg., Bacchus Imports, Ltd. v. Dias, 468 U.S. 263 (1984); Westinghouse Elec. Corp. v. Tully, 466 U.S. 388 (1984); Maryland v. Louisiana, 451 U.S. 725 (1981); Boston Stock Exch. v. State Tax Commn., 429 U.S. 318 (1977).

12. Western Live Stock v. Bureau of Revenue, 303 U.S. 250, 255-56 (1938) (citations omitted).

13. Armco, Inc. v. Hardesty, 467 U.S. 638, 644 (1984) (quoting Container Corp. of America v. Franchise Tax Bd., 463 U.S. 159, 169 (1983)) (bracketed word in original).

14. See cases cited in note 11 supra. The only other decision invalidating a levy on commerce clause grounds during the past decade was Japan Line, Ltd. v. County of Los Angeles, 441 U.S. 434 (1979), a decision that turned on considerations peculiar to state taxation of foreign commerce, with which Regan is not concerned. See Regan, supra note 6, at 1177 n.156.

15. 468 U.S. 263 (1984).

16. The Court did observe, however, that "[a] finding that state legislation constitutes 'eco- 
inghouse Electric Corp. v. Tully, ${ }^{17}$ the Court struck down an income tax credit explicitly designed by the legislature to favor in-state over out-of-state activity. In Maryland v. Louisiana, ${ }^{18}$ the Court struck down a taxing scheme that was deliberately designed to shield local economic activity from the impact of the exaction. In Boston Stock Exchange v. State Tax Commission, ${ }^{19}$ the Court struck down a levy specifically intended to improve the competitive position of local vis-àvis out-of-state stock exchanges. In Armco, Inc. v. Hardesty, ${ }^{20}$ the Court struck down a tax that subjected interstate business to the risk of cumulative tax burdens not borne by local commerce. ${ }^{21}$

The Court's decisions over the past decade sustaining state taxes over commerce clause objections ${ }^{22}$ likewise support the hypothesis that the Court views its essential responsibility as safeguarding taxpayers from purposeful economic protectionism and cumulative tax burdens. These decisions, however, do raise questions regarding the precise nature of its commitment to those goals. For example, the Court (like Regan) found no purposeful discrimination in Common-

nomic protectionism' may be made on the basis of either discriminatory purpose or discriminatory effect." 468 U.S. at 270 (emphasis added) (citations omitted).

17. 466 U.S. 388 (1984).

18. 451 U.S. 725 (1981).

19. 429 U.S. 318 (1977).

20. 467 U.S. 638 (1984).

21. Although Armco involved a tax that the Court also characterized as discriminatory, 467 U.S. at 639,644 , it is questionable whether the discrimination was "purposeful economic protectionism," as Regan has employed that phrase. The allegedly discriminatory provision at issue in Armco was part of West Virginia's broad-based Business and Occupation Tax, imposed on the privilege of engaging in business in the state and measured by the gross receipts from the business. The levy embraced most business activity in the state, including manufacturing, selling, contracting, banking, public utility and other services, and natural resource production. In general, if a taxpayer were engaged in two different business activities, it would pay a tax for the privilege of engaging in each activity upon the specified measure and rate for that activity. There was an exception to this general pattern, however, with respect to enterprises engaged in both manufacturing and wholesaling in the state. Although such an enterprise would in principle be subject to both the manufacturing and the wholesaling tax, the statute provided that any person exercising the taxable privilege of manufacturing was not required to pay the tax otherwise imposed on those exercising the taxable privilege of wholesaling. The legislative purpose underlying this exemption was clearly to avoid duplicative taxation of taxpayers engaged in closely related activities in the state. Nevertheless, it facially discriminated against the out-of-state manufacturer who made wholesale sales in West Virginia: such a manufacturer would pay a wholesaling tax to West Virginia from which the local manufacturer-wholesaler would be exempt (because it had paid a manufacturing tax). Despite the fact that the facial discrimination did not result in actual discrimination because the manufacturing tax paid by the local manufacturerwholesaler was greater than the wholesaling tax paid by the out-of-state manufacturer-wholesaler, the Court pointed out that if other states were to impose taxes similar to West Virginia's, interstate manufacturer-wholesalers would suffer because they "will pay both a manufacturing tax [to the state of manufacture] and a wholesale tax while sellers resident in West Virginia will pay only the manufacturing tax." 467 U.S. at 644.

22. See cases cited in note 1 supra, other than the cases discussed in the preceding paragraph and Japan Line, Ltd. v. County of Los Angeles, 441 U.S. 434 (1979), discussed in note 14 supra. 
wealth Edison Co. v. Montana, ${ }^{23}$ where Montana imposed a thirty percent severance tax on coal, virtually all of which was shipped outside the state. Because the state had moved to dismiss the taxpayers' complaint, it was assumed that the tax was exported along with the coal and that the tax bore no quantitative relationship to the value of services provided by the state. Hence the fundamental issue was whether the commerce clause imposed any limits on the level of a state tax borne by out-of-state taxpayers. There was, to be sure, no discrimination, purposeful or otherwise, between local and out-of-state consumers. Yet it was alleged that Montana had deliberately selected coal (remember the energy crisis?) "as the object of this extraordinary tax ... to export the practical effect of the tax to consumers in other states." 24 One could thus argue, as I did some years ago, that

the State's effective selection of a class of out-of-state taxpayers to shoulder a tax burden grossly in excess of any costs imposed directly or indirectly by such taxpayers on the State places an unconstitutional burden upon interstate commerce. For the Court has made it clear that facially nondiscriminatory taxes which by their practical operation discriminate against interstate commerce are vulnerable to attack on Commerce Clause grounds. While the States need not fine-tune the exercise of their taxing power to accord with a precise accounting of the costs imposed by and benefits provided to the taxpayer, they should not be permitted to single out the nonresident taxpayer to bear the brunt of a demonstrable imbalance on this score, at least if it can be shown that other levies with a less selective impact do not suffer from such an imbalance. ${ }^{25}$

Regan accurately observes that I have more recently shown myself to be "sympathetic ... [to] Montana's point of view"26 - sympathy acquired, no doubt, in the course of three years of litigating the case on behalf of the State of Montana. ${ }^{27}$ And he is right in intimating that I believe that Commonwealth Edison was correctly decided. My view, however, is based on the firm conviction that the Court is an institutionally incapable and politically inappropriate body for determining the appropriate level of a tax. ${ }^{28}$ I remain uncomfortable with the notion that shifting the burden of the costs of state government to out-of-

23. 453 U.S. 609 (1981).

24. Brief for Appellants at 8, Commonwealth Edison Co. v. Montana, 453 U.S. 609 (1981) (No. 80-581).

25. Hellerstein, Constitutional Constraints on State and Local Taxation of Energy Resources, 31 NATL. TAX J. 245, 249 (1978) (footnotes omitted).

26. Regan, supra note 6 , at 1171 .

27. I have consistently disclosed this fact in writing about Commonwealth Edison, including the article cited by Regan. See McGrath \& Hellerstein, Reflections on Commonwealth Edison Co. v. Montana, 43 MONT. L. Rev. 165, 165 (1982).

28. See Hellerstein, Constitutional Limitations on State Tax Exportation, 1982 AM. BAR FOUND. RES. J. 1, 54-59. 
staters can never be regarded as purposeful economic protectionism so long as local economic actors are not favored over their out-of-state competitors. Even accepting Regan's view that citizens "as beneficial owners of the state's revenues . . . do not compete with foreign consumers,"29 I am not yet willing to abandon the principle that requiring interstate commerce to pay more than its way discriminates against interstate commerce at least when intrastate commerce generally is not so burdened, even if there is no judicial remedy for that discrimination under the commerce clause.

Another troublesome case that arguably involves both purposeful economic protectionism and cumulative tax burdens is Moorman Manufacturing Co. v. Bair. ${ }^{30}$ In Moorman, the Court sustained the constitutionality of Iowa's single-factor sales formula for apportioning corporate income. The taxpayer manufactured and sold animal feeds. All of its products sold to Iowa customers were manufactured in Illinois. The taxpayer sought to demonstrate that Iowa's single-factor formula for apportioning net income, when considered in conjunction with Illinois' three-factor formula of property, payroll, and sales, subjected income derived from its Iowa sales to duplicative taxation in violation of the commerce clause. ${ }^{31}$

Although the taxpayer had failed to prove that it had in fact been subjected to duplicative taxation, the Court proceeded to address the commerce clause questions raised by the two conflicting formulas on the assumption that they produced "some overlap" 32 in the taxation of the taxpayer's income. The taxpayer had contended that "to the extent this overlap is permitted, the corporation that does business in more than one State shoulders a tax burden not shared by those operating entirely within a State." 33 The Court responded that " $[t]$ he only conceivable constitutional basis for invalidating the Iowa statute would be that the Commerce Clause prohibits any overlap in the computation of taxable income by the States."34 But it noted that because

29. Regan, supra note 6 , at 1244.

30. 437 U.S. 267 (1978). In the interest of full disclosure, it should be noted that I was of counsel to the Iowa Manufacturers Association, et al., which submitted a brief amici curiae supporting the state in Moorman. Needless to say, the views expressed here are entirely my own and do not necessarily - indeed, almost certainly do not - reflect the views of the Iowa Manufacturers Association, et al.

31. The taxpayer also claimed that the formula resulted in extraterritorial taxation in violation of the due process clause, but the Court rejected this argument on the ground that the taxpayer had failed to prove that income attributed to lowa was in fact earned in Illinois. 437 U.S. at 271-75.

32. 437 U.S. at 277.

33. 437 U.S. at 277.

34. 437 U.S. at 278. 
the risk of such overlap may exist any time a multistate firm does business in states having different division-of-income rules, a constitutional requirement of precisely apportioned income would have unacceptably broad consequences because it would require the Court to prescribe uniform rules of income attribution among the states. The Court concluded that "the legislative power granted to Congress by the Commerce Clause of the Constitution would amply justify the enactment of legislation requiring all States to adhere to uniform rules for the division of income," $" 35$ and that such policy decisions should be made by the body to which they are constitutionally committed. In thus rejecting the taxpayer's invitation to forge the commerce clause into a tool for constitutionalizing division-of-income problems, the Court made it plain that, in this context, the cumulative-burden doctrine has a more limited role to play than once might have been envisioned.

Regan has no difficulty with the Court's decision in Moorman, despite its tolerance of cumulative tax burdens on the interstate firm "just because the firm is interstate": 36 "Nonuniformity in methods that are perfectly fair considered individually can result in adventitious burdening of interstate commerce. But this the Court has quite reasonably decided not to worry about." 37 If Regan's premises are sound, I would have little quarrel with his conclusion. But are those premises sound? Even though the single-factor sales formula passes the test of "internal consistency" - i.e., if every state employed it, the interstate business would be taxed no more heavily than its intrastate competitor - it flunks the test of fairness. As the Court pointed out in General Motors Corp. v. District of Columbia, ${ }^{38}$ in striking down the District's single-factor sales formula on statutory grounds:

While the Court has refrained from attempting to define any single appropriate method of apportionment, it has sought to ensure that the methods used display a modicum of reasonable relation to corporate activities within the State. ... The standard three-factor formula can be justified as a rough, practical approximation of the distribution of either a corporation's sources of income or the social costs which it generates. By contrast, the geographic distribution of a corporation's sales is, by itself, of dubious significance in indicating the locus of either factor. ${ }^{39}$

Furthermore, it is questionable whether the risk of cumulative burdens created by Iowa's single-factor sales formula was truly "adventitious." Even in 1965, the Court knew that

\footnotetext{
35. 437 U.S. at 280.

36. Regan, supra note 6, at 1187.

37. Id. at 1186 n. 180 .

38. 380 U.S. 553 (1965).

39. 380 U.S. at 561.
} 
[t]he great majority of States imposing corporate income taxes apportion the total income of a corporation by application of a three-factor formula which gives equal weight to the geographical distribution of plant, payroll, and sales. The use of an apportionment formula based wholly on the sales factor, in the context of general use of the three-factor approach, will ordinarily result in multiple taxation of corporate net income .... .40

By 1978, forty-four out of the forty-five states other than Iowa that imposed corporate income taxes employed the three-factor formula. ${ }^{41}$ If the Court can consider other states' laws or practices in the commerce clause calculus for determining the validity of state regulations of interstate transportation, ${ }^{42}$ which it apparently can do without objection from Regan, ${ }^{43}$ why can it not do the same thing in the tax cases to protect interstate taxpayers from bearing heavier tax burdens than their intrastate competitors merely because the former engage in interstate commerce? ${ }^{44}$

Finally, even if one believes that the Court has no business invalidating apportionment formulas under the commerce clause on the basis of their relative fairness, and that commerce clause decisions (at least in the tax field) should not turn on the current configuration of other states' legislation, there remains the question whether Iowa's statute amounted to purposeful economic protectionism. It is no secret that Iowa is a market state. Insofar as out-of-state businesses are engaged in economic activity in Iowa it is likely to be through sales to Iowa customers. Moreover, insofar as local businesses are engaged in economic activity outside Iowa it is likely to be through sales to outof-state customers. Hence Iowa's adoption of a single-factor sales formula in the context of the general use of a three-factor formula by other states imposes a lower total income tax burden on Iowa-based businesses doing business in other states than on similarly situated outof-state businesses doing business in Iowa. ${ }^{45}$ The effect is to improve the economic position of the Iowa-based business over its foreign competitor by minimizing the state tax burden of the former and maximizing the state tax burden of the latter. It takes no great feat of imagination to conjure up the legislative purpose underlying the Iowa statute, and it is a purpose that comes awfully close to Regan's defini-

40. 380 U.S. at 559 (footnote omitted).

41. Moorman, 437 U.S. at 283 (Powell, J., dissenting).

42. See Southern Pac. Co. v. Arizona ex rel. Sullivan, 325 U.S. 761 (1945); Bibb v. Navajo Freight Lines, 359 U.S. 520 (1959).

43. See Regan, supra note 6, at 1182-85.

44. See Moorman, 437 U.S. at 293-97 (Powell, J., dissenting).

45. Moorman, 437 U.S. at 283-85 (Powell, J., dissenting). 
tion of purposeful economic protectionism. And while I am not proposing that we resolve these cases on the basis of guilt by association, it is not without relevance that the Iowa Manufacturers Association filed an amicus brief supporting the validity of Iowa's single-factor sales formula. 46

\section{II}

In the course of sketching the broad outlines of his dormant commerce clause theory, with its admittedly "brief" and "oversimplified"47 treatment of the taxation area, Regan nevertheless makes several specific observations about the tax cases that warrant similarly specific comments:

(1) Regan suggests that the "national interest in not subjecting interstate commerce to special disadvantage just because of its interstate character ... may account for the rule of Freeman v. Hewit that an interstate sale may not be taxed by the state of the seller."48 The "rule" of Freeman v. Hewit 49 as articulated by the Court was that a "direct" tax on the proceeds from interstate sales violated the commerce clause wholly apart from any question of discrimination or cumulative tax burdens. ${ }^{\text {so }}$ That rule of absolute immunity of interstate commerce from state taxation was explicitly repudiated by the Court in Complete Auto Transit, Inc. v. Brady. ${ }^{51}$ To be sure, one may recast the "rule" as an effort by the Court to prevent cumulative taxation in light of the presumed power of the state of the buyer to impose a tax on the interstate sale. ${ }^{52}$ Nevertheless, it remains unclear under the Court's contemporary commerce clause doctrine whether the Court would require the state of origin or the state of destination to yield, assuming both had nexus with the sale and each sought to tax it. ${ }^{53}$ It would seem that the Court would not permit both states to tax the transaction on an unapportioned basis, yet the Court "has expressly reserved the question whether a State must credit a sales tax paid to

\footnotetext{
46. See note 30 supra.

47. Regan, supra note 6 , at 1185 .

48. Id. at 1187-88 (footnote omitted).

49. 329 U.S. 249 (1946).

50. 329 U.S. at 254-57.

51. 430 U.S. 274 (1977).

52. Regan, supra note 6, at 1188; see also Hellerstein, State Taxation of Interstate Business and the Supreme Court, 1974 Term: Standard Pressed Steel and Colonial Pipeline, 62 VA. L. REV. 149, 172 (1976).

53. The most perceptive judicial discussions of this problem appear in the separate opinions of Justice Rutledge in Freeman, 329 U.S. at 259.83 (concurring), and in International Harvester Co. v. Department of Treasury, 322 U.S. 340, 349-62 (1944) (concurring and dissenting).
} 
another State against its use tax." 54

(2) Regan recognizes that a compensating use tax could be part of a protectionist scheme "if, for example, a state that made furniture mainly out of oak imposed a sales tax and a compensating use tax only on furniture made out of maple."5s $\mathrm{He}$ goes on to note that "[h]ere, as elsewhere, purpose is the crucial question."56 Purpose is not, however, the only question raised by such a case. In Halliburton Oil Well Cementing Co. v. Reily, ${ }^{57}$ the Court examined the application of Louisiana's use tax to specialized equipment purchased and assembled outside the state for use in the state. The focus of the controversy was the appropriate measure of the use tax as applied to a taxpayer who purchased and assembled equipment outside the state. The statute defined the measure of the tax as the full value of equipment purchased outside the state, including the value of the taxpayer's labor and overhead attributable to its out-of-state assembly. Had the taxpayer purchased and assembled this equipment in Louisiana, it would have been subject to a sales tax measured only by the cost of the articles purchased, without inclusion of the labor costs or overhead.

It is difficult to believe that the discrimination against out-of-state assemblers of equipment was purposeful. In Louisiana, as elsewhere, the sales tax base has generally been limited to sales of tangible personal property. Unless the sales tax statute specifically so provides, sales of services have not been taxable. The use tax base is generally defined in terms of the "cost price" of the item used in the state, which ordinarily would be equivalent to the sales price of the item if sold at retail in the taxing state. In cases in which a final product is purchased at retail, these definitions will give rise to no inequality between in-state and out-of-state purchases, because the tax bases will be identical. Hence, in all but a handful of cases, Louisiana's taxing scheme would work without constitutional hitch because the out-ofstate purchaser would be saddled with a use tax in Louisiana on the out-of-state purchase identical to the sales tax he would have paid in Louisiana had he purchased the item there. The problem in Halliburton was that the scheme did not work for the peculiar case of the outof-state self-assembler of property brought into Louisiana. The Court quite properly struck down the tax because it discriminated against the out-of-state purchaser-assembler as compared with its in-state counterpart. Purpose, however, was irrelevant. Indeed, the Court de-

54. Williams v. Vermont, 472 U.S. 14, 21-22 (1985).

55. Regan, supra note 6 , at 1256.

56. Id.

57. 373 U.S. 64 (1963). 
clared that "[w]hile the inequality in question may have been an accident of statutory drafting, it does in fact strike at a significant segment of economic activity and carries economic effects of a type proscribed by many previous cases." 58

Halliburton is nevertheless quite consistent with Regan's broad commerce clause theory. The case can easily be explained as one that placed the interstate business at a competitive disadvantage merely because it was interstate.

(3) Regan poses the question whether, in the absence of a local sales tax, a state could "adopt a use tax applicable only to imported goods and ... defend the use tax on the ground that local retailers pay higher property taxes than foreign retailers, or that foreign retailers pay lower payroll taxes than their local counterparts."59 Regan's answer is negative, and he suspects that the Court's would be also, although he acknowledges that "[t]he Court's view on 'equalizing' taxes may be more generous than mine."60 In fact, the Court has struggled for years with "complementary" or "compensatory" taxes that are offered by the states as a defense to taxes that appear to discriminate against interstate commerce. ${ }^{61}$ Recently the Court has taken a narrow view of the complementary tax doctrine, ${ }^{62}$ suggesting that Regan's negative answer would be shared by the Court. Nevertheless, in light of the Court's precedents sustaining as "complementary" taxes whose relationship to one another has been unsettlingly loose, ${ }^{63}$ the precise contours of the doctrine remain uncertain.

(4) I should finally address the case where my differences with Regan seem greatest. Regan takes me to task for suggesting that the decision in Henneford v. Silas Mason Co. ${ }^{64}$ which sustained the constitutionality of a compensating use tax scheme, countenanced a form of protectionism by interfering with interstate tax competition. ${ }^{65}$ In the article that Regan cites, ${ }^{66} \mathrm{I}$ had relied in turn on Professor Ernest Brown, who had inquired:

58. 373 U.S. at 72.

59. Regan, supra note 6 , at 1257.

60. Id.

61. See generally Hellerstein, Complementary Taxes as a Defense to Unconstitutional State Tax Discrimination, 39 TAX LAw. 405 (1986).

62. See Armco, Inc. v. Hardesty, 467 U.S. 638, $642-43$ (1984); Maryland v. Louisiana, 451 U.S. 725, 758-60 (1981).

63. Alaska v. Arctic Maid, 366 U.S. 199, 204-05 (1961); Railway Express Agency, Inc. v. Virginia, 358 U.S. 434 (1958).

64. 300 U.S. 577 (1937).

65. Regan, supra note 6 , at $1252-55$.

66. Hellerstein, Federal Limitations on State Taxation of Interstate Commerce, in 2 CourTs and Free Markets: Perspectives from the United States and Europe 431, $461-62$ (T. 
Should one state in a federal system be able to raise its price levels, isolate itself and protect its markets from the outside price competition thereby stimulated? Or does the federal system demand at least that degree of economic unity which would require that consumers and buyers within the state have some measure of access to a free market outside? ${ }^{67}$

To Regan's charge that my views were ill-conceived, I can only plead nolo contendere, a plea I had actually entered in print, although admittedly without formally recanting my earlier views:

Insofar as a use tax simply assures that a tax is paid on all consumption, whether from in-state or out-of-state producers, such a tax is not "protective" as that term is generally understood. A protective tariff is traditionally viewed as a levy that singles out the foreign product for taxation to which the local good is not subjected in order to protect the local good from foreign competition. ... [R]aising domestic price levels is not generally regarded as protectionism. Moreover, Professor Brown's assumption that a state with a broad-based consumption tax can isolate itself and protect its market from outside competition is ill-founded because in-state producers are given no artificial tax advantage by a use tax that merely mirrors a sales tax, and higher in-state prices will discourage instate purchases by residents of other states. ... Professor Brown's concerns are rooted in the notion that the federal system gives consumers in states with consumption taxes the right to escape such taxes by purchasing goods in states without consumption taxes. Although this might correspond to Professor Brown's view of "access to a free market," it is at odds with the Court's modern commerce clause opinions that have repudiated the idea that the commerce clause creates a tax free zone of immunity for interstate commerce. ${ }^{68}$

Sandalow \& E. Stein eds. 1982). Regan also cites my comments in the symposium discussion in Regulation, Federalism, and INTERState Commerce 125 (A. Tarlock ed. 1981).

67. Brown, The Open Economy: Justice Frankfurter and the Position of the Judiciary, 67 YALE L.J. 219, 234 (1957).

68. Hellerstein, supra note 61, at 409 n.24. 